\title{
REPORT ON A VISIT TO AL WALID LEPROSARIUM, DAMASCUS, SYRIA
}

by Albert E. H. van Gorkum, Esq., M.I.L.A., M.o. of ch., M.M.h.I).

\section{General}

In Syria, when a leprosy case is discovered, the Government requires that the patient be transferred to the leprosarium. This is done under the responsibility of the police and is a very difficult task, because the patient is reluctant. He is generally repudiated by his family, and moreover, if married, his own relatives do not wish to be associated with him. For this reason the difficulty of caring for a leprosy patient is great.

The Al Walid Hospital, Leprosarium Kouseir, is located on the road from Damascus to Aleppo, about $18 \mathrm{~km}$. north of Damascus. There is a big mental hospital facing the leprosarium. The leprosarium is secluded by a wood and a high wall and is surrounded by land, mostly of agricultural nature. I visited there on 18 th November, 1958.

Patients come to this leprosarium from Syria: Djebel-el-druze (Kafar laha); Hauran (Sanamain, Mahajjeh, Souda and Housoun); Lattakia (Brumaneht-Mashaekh, Aramo and Tel-Kalakh); Aleppo (Al-Bab); Lebanon: Baalbek (Hurmel); Sidon; Tyre; and Palestine, 4 refugees.

\section{Finances}

The Government pays all expenses of the patients, but individual patients receive no cash subsidy.

The Wakf, which is an institution handling the allocation or the dedication of lands or other property to some beneficial or pious enterprise, contributes about 125 Syrian pounds, equivalent to about U.S. $\$ 32.60$

The financial status of the leprosarium at the moment is rather unsound, because of inadequate cash resources and uncertainty of future income. There are very few voluntary contributions either in cash or in kind.

\section{Staff and Personnel}

The existing staff comprises the Medical Director in charge of the leprosarium, Dr. Izzat Roumani, who is a physician but not a specialist in leprosy. Although his speciality is psychiatry, he approaches his duties seriously. There is also a male nurse, $\mathrm{Mr}$. Adel Rabia, and a female nurse, Wisal Daghoustani, in charge of the nursing staff. They have received no special training in leprosy work but have held their posts for the past 11 years in this leprosarium and also take their responsibilities very seriously. 
The auxiliary staff is made up of 16 men and women; one of these is the porter at the gate and he does not have any close contact with the patients.

Training of medical staff could be done; it only needs arrangement and the provision of modern equipment and financial resources. Training of auxiliaries could also be done if qualified social workers and those skilled in rehabilitation and physiotherapy were available.

\section{Capacity of the Leprosarium}

At present there are 120 patients, but there is adequate space for 20-30 more patients. The possibility for expansion exists but this would involve reducing the recreation ground for the patients.

\section{Patients}

The patients enter the leprosarium in different stages and all suffer from mixed types of leprosy. Up to date there are in the leprosarium 120 patients divided into:

\begin{tabular}{|c|c|c|c|c|}
\hline Sex & Age & Single & Married & Total \\
\hline Females & $12-90$ & 28 & 20 & 48 \\
\hline Males & $15-100$ & 52 & 20 & 72 \\
\hline & & 80 & 40 & 120 \\
\hline
\end{tabular}

Only 2 couples have children, one with 2 girls and 2 boys, and the other with 3 girls and 1 boy. Five of these children are in the leprosarium with their parents but are not yet infected. One was adopted by a family and 2 were entrusted to a special institution outside.

\section{Treatment}

In surgical treatment minor amputations are done for ulcers and deformities of the limbs, and in medical treatment there are several drugs used in this leprosarium: Diasone is sometimes combined with several other drugs such as Nicotibine, Dusolone, Sulphetrone, Cimedone (Specia), and Ciba 1906, which is still under test but the results of which have been successful up to now.

\section{Discharge from the Leprosarium}

Only 1 patient was discharged from the leprosarium in the past 20 years. The eligibility for discharge from the leprosarium is based only upon bacterial negativity.

\section{Living Accommodation for the Patients}

There are 4 pavilions for the patients, 1 for male patients, 1 for female patients, 1 for invalid male patients, and 1 for the operating room and for all the members of the staff and employees. Each pavilion accommodates 27 patients and there is a general dining room. Married couples live in wooden cottages built by themselves. 


\section{Hygienic Condition of the Leprosarium and its Surroundings}

Generally speaking the hygienic conditions are good. All the wards and cottages are clean and well-kept. In the grounds are a shop and a store run by the patients themselves and poultry are also kept, the eggs and the birds being sold outside to provide extra money.

The operating room I did not see but was assured that it was in good condition. It is used once every 3 months when a surgeon from a neighbouring hospital comes to perform minor operations, such as correcting limbs, etc.

\section{Dietary Regulations and Distribution of Food and Foodstuffs}

Every day at a regular time, the patients get their food from a central kitchen. This food is the same as for the people outside, but of much better quality. Patients are allowed to have meals other than the regular meals. They have to prepare these themselves and can have them whenever they like.

\section{Social Factors}

Social amenities are, generally speaking, very poor and inadequate. When a patient enters the leprosarium he is dead for his own family and nobody pays any more attention to him. Consequently most of them prefer to stay in the leprosarium and this is an economic strain on the institution. This is one of the numerous reasons why people from outside are afraid to consult a physician, because if they happen to be diagnosed as suffering from leprosy, they know what kind of social consequences ensue.

No social worker visits the leprosarium. Consequently the patients are deprived of all outside contact. The leprosarium sometimes receives gifts. For males it is mostly second-hand clothing or obsolete military uniforms.

The social relationship between the patients is tolerable, except during the first three to four months during which they are more or less difficult. This is understandable. They have lost their freedom, their relatives, virtually everything. Sometimes there are some discords between the patients, often due to differences of political character. The patients are not exclusively Syria nationals. It is due to the efforts of the Medical Director and the nurse that these quarrels are mitigated and eliminated. Not only by their authority, but also by their human understanding and approach to the circumstances of the patients, they assist in the resolution of these problems.

Another very important factor is the marriage of the patients and the resulting offspring. Patients are not allowed to marry outside the leprosarium. Once married they can devise their own manner of living, so that it resembles outside life a little. But perhaps one of the most important problems is the question of the children born of these marriages. There is no law to say that these children shall be taken 
away from their parents. However, from the medical standpoint, it would be advisable and necessary that the children be segregated from the risk of infection. There is no external creche or preventorium. These children have to stay in the leprosarium as long as their parents are inhabitants, which may be for ever. What is the future then for these children? It looks the same as that for the parents. In this leprosarium there have been three exceptions, two children were sent to a special institute and one child was adopted by the nurse of the leprosarium.

\section{Vocational Training}

There is no possibility of this, because of the lack of trained staff and the apathy of the people outside the leprosarium.

\section{Religious Instruction, Educational Care, Welfare Arrangements}

Clergymen come once a year to pay a visit to the patients and to offer them some candy. The patients are without any educational care, and there are no teachers or social workers who could do something for them, so that at least they may learn something to make their lives a little bit more tolerable than is the case at present. The patients have no facilities for sport, mostly because of their invalid status. On the other hand, no one has given them the opportunity to do it or to try it. There is no library, so they cannot even read books.

\section{Hospitalisation and Leave for the Patients}

Patients entering the leprosarium in an advanced stage are kept permanently in the leprosarium. For the other patients there is a possibility of going on short leave and perhaps even later of being discharged from the leprosarium.

If a patient goes on temporary leave, the name of the patient is given to the district medical officer at the patient's destination. If a patient leaves the leprosarium without permission, the police are called to bring the patient back, if necessary by force. So far as is known, in Syria all leprosy patients are under state control.

\section{Problems Mentioned by the Medical Director during my Visit to the Leprosarium}

(a) the lack of persons well trained in leprosy in the medical staff as well as in the nursing staff:

(b) the absence of a scientific library:

(c) the lack of interest outside the leprosarium for the needs, sometimes the urgent needs, of the leprosarium. People outside the leprosarium should be informed about leprosy, so that if there is a case of it they know that it is curable and that they are not social outcasts. 
(d) The leprosarium needs an endowment of money and more donations, so that they can do a lot of most useful things, for example, the building of a recreation room and some special rooms for handicrafts and rehabilitation.

\section{Recommendations}

Much can be done for this leprosarium, where the medical director and the nurse are doing their utmost to carry out their duties with devotion, sometimes under circumstances which are not so very pleasant. The patients are very grateful for what is given to them and for all that is done for them.

It is of primary importance that there should be a possibility for training the medical staff and the nursing staff. They should be adequately remunerated and be given the chance to visit well run leprosaria, so that they can exchange their views about work.

There should be social workers who could take care of the patients inside the leprosarium and their subsequent rehabilitation.

A scientific library for the medical staff and a recreational and vocational library for the patients is an urgent necessity.

Facilities for handicrafts would be desirable to keep the patients occupied and to provide means for physical training.

Patients should be taught skills, commensurate with their mental and their invalid status, so that when they are due for discharge they have a trade and there would not be so many difficulties later. Even in the leprosarium they could use these skills to produce goods for sale outside.

Once or twice a month, there might be a good cinema show for entertainment of the inhabitants of the leprosarium.

There should be close contact with the several religions involved and possibilities of spiritual ministration should be explored and encouraged by both civil and religious authorities.

\section{Acknowledgements}

I wish to express my thanks to Dr. Izzat Roumani, Medical Director of the Al Walid Leprosarium, Damascus, for his courtesy and kindness in helping me to make this report possible; to Dr. Fakir, Director of the Malaria Eradication Service, Damascus, who arranged the opportunity for me of visiting the Al Walid Leprosarium; to Mr. W. F. Beecroft, Ph.D., D.P.A., who assisted me in the preparation of this report.

I was warmly welcomed when I visited the leprosarium by the Medical Director, Dr. Izzat Roumani, and also by the nurse. I was given the opportunity to obtain all the information I wanted and to see everything which I considered relevant. 